\title{
Commonwealth of Independent States: Constitutional, legal and environmental realities
}

\author{
Kim Y.V., Anichkin E.S.* \\ Altai State University, Public University in Barnaul, Russia
}

*Corresponding author E-mail: rrd231@rambler.ru

Received: 09.09.2020. Accepted: 21.10.2020

\begin{abstract}
The formation and development of the Commonwealth took place ambiguously, in difficult conditions, formed under the complex influence of external and internal geopolitical, environmental and inner factors, and did not have the desired dynamics. Successful implementation of the ambitious tasks to further deepen the integration processes in the CIS is impossible without the inclusion of constitutional and legal tools. In the presented work, the authors propose approaches that are possible at the current stage of development of the CIS and its member states to increase the effectiveness of constitutional, legal and institutional support for the development of the Commonwealth.
\end{abstract}

Keywords: Convergence; Environment; Harmonization; Integration; Convergence; Constitutionalism; Constitutional Statehood; Commonwealth of Independent States

\section{Introduction}

In December 2021, the Commonwealth will celebrate the 30th anniversary of its establishment. This major political and legal event on a planetary scale requires appropriate reflection, summarizing and refining the prospects for further development. In accordance with the fundamental documents of the Commonwealth of Independent States (the Agreement on the Establishment of the Commonwealth of Independent States of 08.12.1991, the Declaration of Alma-Ata of 21.12.1991, the Charter of the Commonwealth of Independent States of 22.01.1993) the Commonwealth is a form of cooperation between equal independent states, a regional interstate organization recognized by the international community. The main goal of the Commonwealth is to form in the long-term perspective an integrated economic and political association of interested states ensuring effective development of each of its members. At the same time, the further convergence of national legislations of the CIS member-states in various spheres of multilateral cooperation on the basis of universally recognized principles and norms of international law is defined as one of the promising targets aimed at creation of favorable conditions for further development of national economies and security, strengthening of citizens' welfare, involvement into global political and economic processes (Bobrakova, 2008).

In the initial period of its existence, the Commonwealth was regarded mainly as a mechanism of civilized divorce of former Soviet republics and division of the USSR's property, a way of smooth transition from a single Soviet Union state to an independent existence of sovereign nation-states (BRICS, 2015). At his press conference in Yerevan on March 25, 2005 Putin explained with utmost frankness what the principal differences between European integration and CIS are: "If in Europe the countries within the EU worked together for unification, the CIS was created for civilized divorce. Here is the difference"; "the CIS was created for the most civilized way of disintegration of the USSR. The CIS coped with this task" and at the same time, the CIS "would not have had any super-tasks in environmental integration or economic spheres" (Buzan, Waever, 2003).

And only later, when the aspiration for national-state separateness was rethought in some way, the political and socio-economic costs of the "waves" of sovereignty were discovered, and the motivation for greater rapprochement and integration in the political, economic and other areas increased. Serious steps would have been taken in this direction and major interstate decisions taken.

Meanwhile, throughout the existence of the CIS, despite the notable intensification of legal cooperation in recent years, the issues of constitutional and legal support for the functioning and development of the Commonwealth and its institutions were not addressed. It is also worth paying attention to the absence of comprehensive constitutional and legal studies, in both Russia and the Commonwealth, on the development of constitutional law in the CIS countries under the conditions of supranational integration processes in terms of the relationship between international and domestic law. Although the comparatively oriented studies devoted to the review of certain institutions of constitutional law, as well as state and legal processes in the CIS countries, were carried out rather intensively (D'Anieri, 1997). Among the works of complex character, which partly address some aspects of the state and legal interaction of the CIS countries in the context of globalization and integration processes taking place in other interstate associations with the participation of Russia, a number of major studies carried out under the auspices of the Institute of Law and Comparative Law under the Government of the Russian Federation (Moscow) could be mentioned (Dodonov, 1997).

Foreign research is primarily focused on the analysis of economic or institutional aspects of post-Soviet regionalism, and therefore there are virtually no specific works of a state-oriented nature that develop the issues outlined in this publication (Dostiev, 1999; Dzhangirian, 2014).

\section{Methodology}

According to the Concept of Further Development of the Commonwealth of Independent States, approved by the Decision of the Council of Heads of State of the CIS dated October 5, 2007 (Dushanbe), its distinctive features are the organization of interaction 
practically in all spheres of interstate communication, flexibility of mechanisms and formats of collective cooperation (item 1.1). At the same time, further convergence of national laws of the CIS member-states in various spheres of multilateral cooperation on the basis of universally recognized principles and norms of international law is defined as one of the promising targets aimed at creating favorable conditions for further development of national economies and security, strengthening of citizens' welfare, involvement in global political and economic processes (Globalization, 2014; Haji Zadeh, 2005).

In the composition of factors that systematically affect the quality of integration processes and at the same time limit the disclosure of development potential in the economy, social sphere and other relevant areas of functioning of the CIS member states, we should mention the insufficient level of organizational and legal support for the processes of harmonization of constitutional and legal systems. Synthetic unification of regulatory possibilities of international legal and constitutional-legal instruments in the Commonwealth space is intended to provide "adequate logistics" of integration processes, which have a configuration of "street with multilateral traffic". Many international associations, primarily the European Union, are following this path today and are achieving impressive results. The presented scientific material is based on an interdisciplinary approach based on the synchronization of achievable constitutional, legal and international legal doctrine.

\section{Results}

Inertia and weak activity in the development of the CIS at the initial stage had a known impact on the level of organizational and administrative, resource and legal support of integration processes. In particular, the above-mentioned aspects affected the quality of many founding documents of post-Soviet integration associations with the participation of the Russian Federation. For a long time, many of them were characterized by such a defect as abstract wording. As a result, out of the total mass of pre-convictions and agreements concluded, approximately $75 \%$ are inactive, and the rest have an extremely low effect (Hancock, 2009; Jones Luong, 2002).

An important milestone that has somewhat intensified interstate interaction was the CIS summit in Dushanbe on October 5, 2007, at which the Concept for Further Development of the CIS and the Plan of Basic Activities for its Implementation were approved. In this document, the legal aspects of cooperation were somewhat expanded.

Thus, among the main objectives of the CIS development were identified:

- implementation of fundamental international principles and standards in the sphere of democracy and human rights;

- further convergence of national legislations of the CIS member states in various spheres of multilateral cooperation on the basis of universally recognized principles and norms of international law (paragraph 2.3).

The interparliamentary cooperation of the interested CIS member-states on rapprochement of national legislations, protection of rights and interests of citizens, activation of development of model laws by the Interparliamentary Assembly of the CIS memberstates and their implementation into the legislation of the member-states is designated as one of the priority directions of activity (item 4.3). Based on the presented provisions, the legal cooperation of the CIS countries was identified as an independent area. The Advisory Committee of Heads of Legal Services of the Ministries of Foreign Affairs of the CIS Member States, the Council of Ministers of Justice of the CIS Member States, the Council of Chairmen of Higher Arbitration, Economic and Other Courts that Resolve Cases in Economic Disputes have been established and operate. A unified register of legal acts and other documents of the Commonwealth of Independent States has been formed and is being kept. The CIS Internet portal has a special section entitled "Legal Cooperation" that contains relevant information and analytical materials. Interparliamentary legal cooperation through the CIS Interparliamentary Assembly has become closer and more productive (Gleason, 2010; Miller, 2006).

In accordance with the Convention on the Interparliamentary Assembly of the States Parties to the Commonwealth of Independent States of 26.05.1995, the Interparliamentary Assembly of the Commonwealth of Independent States is an interstate body of the CIS (Art. 1) and is called upon, in particular, to adopt recommendations on the approximation of the legislation of the States Parties; to adopt type (model) legislative acts and send them with the appropriate recommendations to the parliaments of the States Parties to this Convention;

to adopt recommendations to bring the legislation of the States Parties in compliance with the provisions of the international treaties concluded by these States in the framework of the Commonwealth of Independent States (art. 4).

Since 2009, the activities of the Inter-Parliamentary Assembly on Model Law-making are carried out on a planned basis in cooperation with the CIS Executive Committee. According to the Plan of interaction between the CIS Executive Committee and the Secretariat of the Council of the Interparliamentary Assembly of the CIS Member States in single law-making for 2016-2020, normative work is carried out in eight areas: economy; social policy; humanitarian sphere; agrarian policy, ecology and environmental management; military cooperation and security; legal sphere; science and education; state construction and local self-government.

In the first approximation of the presented Plan, a certain haphazardness and structural disarray of directions attracts attention. Among other things, the content of certain areas, especially the "Spheres of State Construction and Local Self-Government", is very poor and does not fully comply with the established ideas about the legal system. Moreover, in the previous planning periods (2009$2010 ; 2011-2015)$ no activities were envisaged in this area at all.

\section{Discussion}

It seems that improvement of the efficiency of the Commonwealth and its institutions is inconceivable without attracting the regulatory potential of constitutional legislation and constitutional law in general. On September 28-29, 2016, Minsk hosted the International Scientific and Practical Conference "25 Years of the Commonwealth of Independent States: Results, Prospects", during which recommendations were made aimed at further development of the CIS across the entire spectrum of interstate interaction. One of the most recent CIS legal acts is the Agreement on Coordination of Interstate Relations in the Field of Basic Research of the Member States of the Commonwealth of Independent States, signed in Ashgabat on May 31, 2019. Among other priority areas of cooperation development, in the framework of which the Parties render all-round assistance to the organizations of the present member-states, the humanities are identified (art. 3).

Thus, the scientific significance and urgency of solving this problem are indisputable. The necessary organizational and legal prerequisites for its development are available. 


\section{Conclusions}

Leading areas of development on the proposed set of fundamental problems could be implemented as a holistic project "Modern Constatus Law of the Russian Federation and CIS countries in the conditions of supranational integration processes: state, trends of development and reserves for improving efficiency". It is assumed that they will be determined in accordance with the approaches to the organization of fundamental scientific research established in the national jurisprudence. They could be preliminary presented in the form of the following thematic sections (blocks).

Section 1: "The Constitutional Space of the Commonwealth of Independent States as a Geopolitical and State Legal Reality: Constitutional and Legal Aspects of Institutional Support for CIS Development". There are fundamental geopolitical and state-legal prerequisites for the legitimacy of statements about the unity of the CIS constitutional space. They derive from the historically established community of political, legal and economic systems, have an organic character, and are found in the genetic kinship of civilization principles and cultural traditions of states and ethnic groups that have generated a single statehood of the Great Russian Empire and the Union - USSR. There is a need for a deep special legal analysis from the perspective of the science of constitutional (state) law: a) the completeness and sufficiency of the institutional framework of the CIS, which should be aimed at promoting and reproducing its values, goals, serving its interests and those of its member states, and ensuring the consistency, efficiency and continuity of its policies and actions, b) the workability and effectiveness of constitutional and legal means to ensure the functioning and development of state and legal institutions of the Soviet Union.

Section 2: "Dynamics of the constitutional and legal space of the Commonwealth of Independent States: basic laws and development trends". At the present stage, there is a high degree of interpenetration of approaches and institutional decisions in constitutional and legal construction between the CIS member-states, and an aspiration to further convergence and integration of many observed modes of public and state life. The section is aimed at a comprehensive study of the patterns and trends in constitutional and legal development of the Russian Federation and the CIS member states.

Section 3: "Constitutionality and constitutional statehood in the CIS space: typology of national models of constitutions and correlation of system forming elements of constitutional order". It would be useful from the theoretical and methodological point of view within the framework of the doctrine of constitutionalism to clarify and doctrinally substantiate the characteristic of parameters (essential features) of constitutional statehood and on this basis to give an assessment of the depth of perception and quality of reproduction of the beginning of constitutionalism in the practice of state building of the Russian Federation and CIS countries. The author presents an important theoretical development of the typology of constitutional models forming in the CIS space and the analysis of the factors influencing the peculiarities of their evolution.

Section 4 "Statehood, supranationality and conventionality: comparative legal analysis of the role and potential of constitutional and legal means in the interstate integration process (European Union, Association of Southeast Asian Nations, League of Arab States, Organization of Islamic Cooperation, African Union, Community of Latin American and Caribbean States, etc.)". The section has a comparative legal orientation and is focused on the analysis and synthesis of international experience of institutional and legal support of integration processes developed in the practice of the largest interstate associations.

Section 5. "Target guidelines and profile directions of integration and harmonization of the CIS constitutional space: urgent problems of improving the institutional and constitutional-legal support". The section is aimed at developing proposals and recommendations to improve the mechanism of constitutional and legal support of integration processes, increase the efficiency of supranational and national state institutions in the implementation of strategic goals and objectives of development of the CIS and its member-states.

The scientific problem on the solution of which it is proposed to orient the direction of research proposed in this article is the current state of constitutional law and constitutional statehood in the Russian Federation and CIS member states, the main regularities and trends that characterize the general dynamics of the constitutional space and institutions of the CIS, as well as doctrinal and contiguous legal support (including the design of legal models and legal structures) of the priority directions.

\section{References}

Bobrakova N.V. (2008). Institute of the Head of State in CIS countries: comparative legal analysis. Thesis of Doctoral Dissertation. Krasnodar.

BRICS: contours of the multipolar world: a monograph (in Russian). (2015). T.Y. Khabrieva (ed.). Moscow: Institute of Legislation and Comparative Law under the Government of the Russian Federation, Jurisprudence.

Buzan B., and O. Waever (2003). Regions and Powers: The Structure of International Security. Cambridge: Cambridge University Press.

D'Anieri P. (1997) International Cooperation among Unequal Partners: The Emergence of Bilateralism in the Former Soviet Union. International Politics 34 (4).

Dodonov V.N. (1997). Constitutional Reforms in the States Emerging in the Territory of the Former USSR. General and Special. Thesis of Doctoral Dissertation. Mosocw.

Dostiev A.S. (1999). Constitution of the Republic of Tajikistan of 1994: History of development, adoption and basic provisions. Thesis of Doctoral Dissertation. Dushanbe, 1999.

Dzhangirian J.D. (2004). Division of Power in the Republic of Armenia: Constitutional Model and Practice. Thesis of Doctoral Dissertation. Moscow.

Gafurov H.M. (2006). Judicial system of the Republic of Tajikistan (comparative legal analysis). Thesis of Doctoral Dissertation. Moscow.

Globalization and Integration Processes in the Asia-Pacific Region (Legal and Economic Research). (2014). T.Y. Khabrieva (Ed.). Moscow: IZISP, INFRA-M.

Haji Zadeh, E.A. (2005). Constitutional models of the form of government and institute of pre-presidency in CIS countries. Thesis of Doctoral Dissertation. Volgograd, 2005.

Hancock K.J. (2009). Regional Integration: Choosing Plutocracy. New York: Palgrave MacMillan.

Jones Luong P. (2002). Institutional Change and Political Continuity in Central Asia. Cambridge: Cambridge University Press.

Gleason A. (2010). Eurasia: What Is It? Is It? Journal of Eurasian Studies 1 (1).

Kainov V.I. (1999). Institute of presidency: Constitutional and legal status. Thesis of Doctoral Dissertation. St.-Petersburg, 1999. 
Khabrieva T.Y. (2016). Constitutional reform in the modern world: Monograph. Moscow: Science of RAS, 2016, etc.

Klishas A.A. (2007). Constitutional Control and Constitutional Justice in Foreign Countries. Thesis of Doctoral Dissertation. M., 2007.

Miller E.A. (2006). To Balance or Not to Balance? Alignment Theory and the Commonwealth of Independent States. Aldershot: Ashgate.

Molchanov M. (2009). Regionalism in Eurasia, in: Fagan G. H., and R. Munck (eds) Globalization and security: An Encyclopedia. Santa Barbara: Praeger Security International.

Myrzalilov R.M. (2013). Bodies of constitutional justice in the countries of Central Asia: problems of theory and practice. Thesis of Doctoral Dissertation. Moscow.

Obydenkova A. (2011). Comparative Regionalism: Eurasian Cooperation and European Integration: The Case for Neofunctionalism? Journal of Eurasian Studies.

Obydenkova A. (2011). Multi-Level Governance in Post-Soviet Eurasia: Problems and Promises, in: Enderlein H, Walt, S., and M. Zurn (Eds.). Handbook on Multi-Level Governance. Cheltenham: Edward Elgar

Olcott, M.B., Aslund, A. and Garnett, S. (1999). Getting It Wrong: Regional Cooperation and the Commonwealth of Independent States. Wash. Carnegie Endowment for International Peace.

Quoraboyev I. (2010). Around the Names of Region: The Case of Central Asia. UNU-CRIS Working Paper No 5.

\section{Citation:}

Kim, Y.V., Anichkin, E.S. (2020). Commonwealth of Independent States: Constitutional, legal and environmental realities. Ukrainian Journal of Ecology, 10(5), 110-113. 